The University of Maine

DigitalCommons@UMaine

$1-2021$

\title{
The COVID-19 Misinformation Challenge: An Asynchronous Approach to Information Literacy
}

Jennifer Bonnet

Senta Sellers

Follow this and additional works at: https://digitalcommons.library.umaine.edu/lib_staffpub

Part of the Library and Information Science Commons

This Article is brought to you for free and open access by DigitalCommons@UMaine. It has been accepted for inclusion in Library Staff Publications by an authorized administrator of DigitalCommons@UMaine. For more information, please contact um.library.technical.services@maine.edu. 


\title{
The COVID-19 Misinformation Challenge: An Asynchronous Approach to Information Literacy
}

Published version https://www.tandfonline.com/doi/full/10.1080/10875301.2020.1861161

\begin{abstract}
The coronavirus pandemic introduced a "new normal" to the everyday lives of people the world over, including an evolving understanding of the virus's spread and long-term impact. With each new development, misinformation about COVID-19 proliferated, sowing confusion and uncertainty about everything from causes to cures. In response, two librarians designed The COVID-19 Misinformation Challenge, a weeklong program aimed at discerning coronavirus fact from fiction on social media, in the news, and in academic publishing. Based on the number of program participants and their overwhelmingly positive feedback, the Challenge proved to be popular, fun, and educational.
\end{abstract}

Keywords: COVID-19, coronavirus, information literacy, fake news, misinformation

\section{Introduction}

In early 2020, the coronavirus pandemic introduced a "new normal" in the ways people interacted with friends, family members, and colleagues. Large swaths of the population were sent home from work and school, with many people placed under stay-at-home orders (Mervosh et al., 2020) and mandated to follow specific personal protective practices (Gostin et al., 2020). During this time, the world witnessed rapid shifts in our understanding of the coronavirus, and simultaneously, a surfeit of misinformation about COVID-19 (Frenkel et al., 2020; Kouzy et al., 2020; Pennycook et al., 2020). Erroneous or misleading claims about everything from causes to cures appeared in social media feeds, in the news, and in research published or posted online. ${ }^{1}$ The authors saw this as an opportunity to create an engaging, accessible program centered on recognizing and resisting false or misleading information. The result: The COVID-19 Misinformation Challenge.

\section{Literature Review}

Asynchronous learning has taken on great importance during the coronavirus pandemic as instruction has increasingly, and rapidly, moved to online environments (Daniel, 2020; Rapanta et al., 2020; St. Amour, 2020). Although asynchronous learning is not an inherently new concept (one could argue that the very idea of 'homework' represents a form of asynchronous learning), its prevalence as an essential method of information delivery is somewhat novel. Not only have researchers found benefits to asynchronous instruction, such as student engagement with course material (Northey at al., 2015), satisfaction with content delivery (Allen et al., 2013), and a facility for in-depth topic exploration and discussion (Salter et al., 2017), but during the COVID

\footnotetext{
${ }^{1}$ See, for example, the World Health Organization’s Myth Busters page, https://www.who.int/emergencies/diseases/novel-coronavirus-2019/advice-for-public/mythbusters, and Rapid Reviews: COVID-19, which describes itself as "an open-access overlay journal that accelerates peer review of COVID-19-related research preprints to advance new and important findings, and prevent the dissemination of false or misleading scientific news," https://rapidreviewscovid19.mitpress.mit.edu
} 
pandemic in particular, asynchronous education has the added capacity of supporting learners who are negotiating multiple life roles (e.g., parenting and/or caretaking while working from home and taking classes) (Flaherty, 2020; Jorgensen, 2003).

In the early days of the novel coronavirus, as people were shifting to new learning and living arrangements, misinformation about COVID-19 was proliferating. In response, various factchecking organizations and educators developed resources for use by the public at large. These included guidance from the International Federation of Library Associations (2020), "How to Spot Fake News - COVID-19 Edition,” Mike Caulfield's (2020) "Sifting Through the Pandemic: Information Hygiene for the Covid-19 Infodemic,” and NewsGuard's (2020) Coronavirus Misinformation Tracking Center. In an effort to help people determine what qualified as "good" information, these resources focused on assessment skills for a dense and rapidly changing information landscape.

Combining asynchronous learning with strategies for evaluating information about and during a pandemic, the authors designed the COVID-19 Misinformation Challenge. This weeklong program provided participants with strategies and resources to think critically about information they were encountering about the novel coronavirus, whether from friends, family, their favorite news outlet, or in their Google search results. This paper outlines that program, and invites readers to participate in the Challenge.

\section{The COVID-19 Misinformation Challenge}

Each day, for five days, in late May 2020, participants in the Challenge received an email with quiz questions designed to test their knowledge of COVID-19. Participants spent time scrutinizing memes on social media, doctors' credentials, news stories, treatment options, and research about the virus. After each quiz submission, participants received extensive feedback on how to find and evaluate each claim or question, and resources and strategies for digging deeper into the daily topics.

Day 1: The Virus Goes Viral. https://libguides.library.umaine.edu/covid19/day1

Participants were presented with three social media posts about COVID-19 and asked to determine their accuracy. Two were real posts that had gone viral: one was from a Canadian doctor who proclaimed his lack of fear of the coronavirus (this one was true), and a false claim about formula makers providing cases of formula for people whose grocery stores had sold out of the product. A third post was a fabrication intended to look like a BBC News story but in actuality, was created by the authors to present an example of how difficult it can be to assess information on social media that is intended to be both clever and brief. Quiz feedback included strategies for determining the veracity of each post, as well as resources about how to identify fake news during the pandemic and why people are susceptible to false and misleading information. 


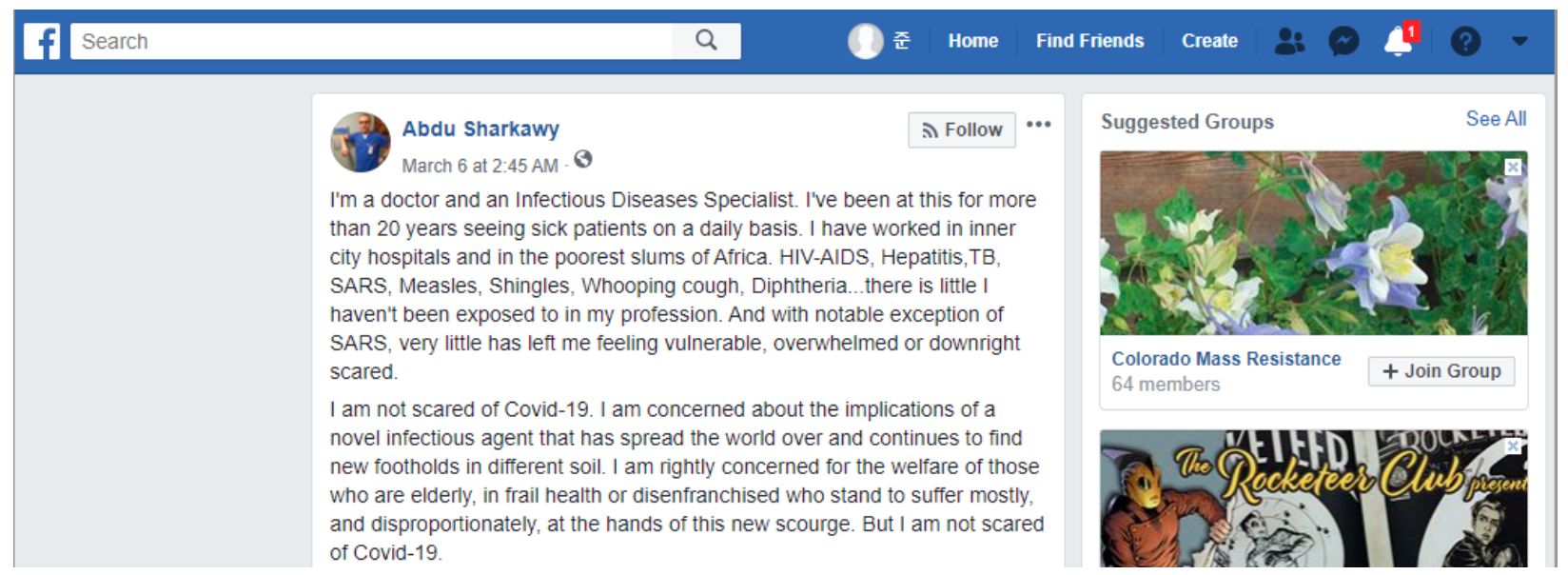

Day 2: Trick or Treatment. https://libguides.library.umaine.edu/covid19/day2

Participants reviewed five statements about possible coronavirus treatments, and determined their trustworthiness. Statements referred to recommendations by leading health organizations regarding treatments found in popular media, like ultraviolet radiation, disinfectants, hydroxychloroquine, remdesivir, and azithromycin. Quiz feedback included guidance from the Centers for Disease Control, the World Health Organization, and COVID Explained. Run by an economist at Brown University and a Professor of Medicine at Harvard Medical School, COVID Explained offered additional insights into common questions about the coronavirus, like whether or not to disinfect one's produce and if one should be concerned about animal exposure to the virus.

\section{Day 3: Doctor or Doctored? https://libguides.library.umaine.edu/covid19/day3}

Participants examined the qualifications of people with "Dr." in their title, and the relevance of their expertise regarding COVID-19. These included a range of titular doctors, from Dr. Fauci and Dr. Birx to Dr. Phil and Dr. Bronner. Feedback on this quiz included search techniques to discern types of medical expertise, affiliations, and contextual factors that contribute to assumptions of authority. Drawing on the Association of College and Research Libraries' Authority is Constructed and Contextual frame (2016), Day 3 emphasized that expertise is measured and applied differently depending on the situation, condition, or circumstance.

\section{Day 4: Fact or Fiction (Toilet Paper Edition). https://libguides.library.umaine.edu/covid19/day4}

Participants were presented with several attention-grabbing headlines about COVID-19 and toilet paper, and asked to determine if the stories were real or fake. Headlines were drawn from National Public Radio, People Magazine, AP News, and Now8News. The first three were real, but many people were stumped by the seeming implausibility of some of the headlines (e.g., "Woman Gives Birth in Toilet Paper Aisle at Missouri Walmart" and “Oregon Police Remind Residents: Don't Call 911 If You Run Out Of Toilet Paper”), whether because of the prevalence of attention-seeking verbiage in news headlines or because truth is sometimes stranger than fiction. Quiz feedback included information on lateral reading as a corroboration strategy, as well as insights into the challenging nature of journalistic coverage of COVID-19, particularly 
given the rapidly changing nature of information about the virus.

\section{Day 4: Fact or Fiction (Toilet Paper Edition)}

Attention-grabbing headlines can make it hard to discern the veracity of a story. The following stories were all published. Is the information in the headline real or fake?
Real
Fake

Headline 2: Oregon Police Remind Residents: Don't Call 911 If You Run Out 1 point Of Toilet Paper, from National Public Radio *
Real
Fake

Day 5: Science or Science Fiction. https://libguides.library.umaine.edu/covid19/day5

Participants discerned the reliability of research published about COVID-19, including studies that had been published, retracted, withdrawn, or were under review. Quiz feedback reemphasized the merits of lateral reading to determine if a paper was under investigation or had been removed from publication, and pointed to Retraction Watch, a scholarly blog and searchable database of retracted articles and justifications for retractions.

\section{Takeaways/Conclusion}

The timeliness of the program, and its asynchronous design, led to an overwhelmingly positive response from participants. We not only marketed this program to our campus departments and 
student lists, but also to professionals and educators with a stake in information literacy.2 As a result, over 500 people joined the Challenge, from New England to the Pacific Northwest, and in international locations like Mexico, Singapore, and Bangladesh. We heard from educators, students, librarians, archivists, and community members who took pleasure in the daily quizzes, whether on their own or in groups (for example, with family members, friends, students, and colleagues). Anonymous feedback about participants' experiences with the program pointed to a general appreciation for a topical, educational diversion. For example, one participant noted, "It was nice to have a short, interesting, useful activity that wasn't work!” while another shared, "Not sure how I found this or you found me but grateful." Several respondents mentioned that they would be using or adapting the program in their instruction, and others found that they learned something new, despite being well versed in all things COVID-19: "This was a lot of fun, and even following the situation closely, there were things I learned that I hadn't known about.” Lastly, it was clear that people recognized the effort it takes to be critical of information they encounter online, and the need for scrutiny: “There were some questions I couldn't answer unless I took the time to research the article and confirm its accuracy. The value of [the Challenge] was the awareness that it's almost impossible to judge the validity of an article or posting unless you see it in context or can go research it. It doesn't really matter how knowledgeable one is on the general topic.”

Additional feedback provided ways in which we could improve upon the challenge going forward. Several respondents recommended explicitly mentioning that participants could search for answers online rather than simply guess at the quiz questions. Other feedback included wording suggestions for some of the quiz questions, such as having multiple answer options versus one alone. This was of particular interest on Day 5 when some of the research articles could arguably be "valid" and "controversial" or "discredited" and "controversial." Lastly, most participants felt that five days was "just right” but a few were interested in a longer challenge with additional quizzes. This feedback will be key to shaping future iterations of the Challenge.

The spread of misinformation about COVID-19 continues, suggesting that more educational programming and outreach are paramount. Even though our Challenge ended in May 2020, interest in the program has stayed strong, with nearly 2000 visits to the site between June and mid-September. The Challenge remains accessible at https://libguides.library.umaine.edu/covid19. Anyone interested in taking the Challenge or adapting it for instruction can access the full range of materials, as well as provide feedback to the authors.

Given the success of this model of information literacy instruction (and outreach), our library continues to design challenges that engage a wide audience on topical issues. Thus far, these have included a racial justice challenge that took place in the summer of 2020, and a news literacy challenge that took place during Media Literacy Week in October of the same year. Like the COVID-19 Misinformation Challenge, these subsequent programs have been popular within and beyond our university community. Whether one is teaching during a pandemic or aiming to reach a large swath of the public with relevant programming, an online, asynchronous challenge presents one way to enrich content and engage people across time and space.

\section{References}


Allen, M., Omori, K., Burrell, N., Mabry, E., \& Timmerman, E. (2013). Satisfaction with distance education. Handbook of distance education, 3, 143-154.

Association of College and Research Libraries. (2016). Framework for information literacy for higher education. http://www.ala.org/acrl/standards/ilframework

Caulfield, M. (2020). Sifting through the coronavirus pandemic. https://infodemic.blog/

Daniel, S. J. (2020). Education and the COVID-19 pandemic. Prospects, 1-6.

Flaherty, C. (Apr 2020). Zoom boom. Inside Higher Ed.

https://www.insidehighered.com/news/2020/04/29/synchronous-instruction-hot-right-now-itsustainable

Frenkel, S., Alba, D., \& Zhong, R. (2020). Surge of virus misinformation stumps Facebook and Twitter. The New York Times. https://www.nytimes.com/2020/03/08/technology/coronavirus$\underline{\text { misinformation-social-media.html }}$

Gostin, L. O., Cohen, I. G., \& Koplan, J. P. (2020). Universal Masking in the United States: The Role of Mandates, Health Education, and the CDC. JAMA.

International Federation of Library Associations. (July 2020). How to spot fake news - COVID19 edition. https://www.ifla.org/publications/node/93015

Jorgensen, D. (2003). The challenges and benefits of asynchronous learning networks. The Reference Librarian, 37(77), 3-16.

Kouzy, R., Abi Jaoude, J., Kraitem, A., El Alam, M. B., Karam, B., Adib, E., ... \& Baddour, K. (2020). Coronavirus goes viral: quantifying the COVID-19 misinformation epidemic on Twitter. Cureus, 12(3).

Mervosh, S., Lu, D., \& Swales, V. (Apr 2020). See which states and cities have told residents to stay at home. The New York Times. https://www.nytimes.com/interactive/2020/us/coronavirusstay-at-home-order.html

NewsGuard. (2020). Coronavirus misinformation tracking center. https://www.newsguardtech.com/coronavirus-misinformation-tracking-center/

Northey, G., Bucic, T., Chylinski, M., \& Govind, R. (2015). Increasing student engagement using asynchronous learning. Journal of Marketing Education, 37(3), 171-180.

Pennycook, G., McPhetres, J., Zhang, Y., Lu, J. G., \& Rand, D. G. (2020). Fighting COVID-19 misinformation on social media: Experimental evidence for a scalable accuracy-nudge intervention. Psychological science, 31(7), 770-780. 
Rapanta, C., Botturi, L., Goodyear, P., Guàrdia, L., \& Koole, M. (2020). Online university teaching during and after the Covid-19 crisis: Refocusing teacher presence and learning activity. Postdigital Science and Education, 1-23.

Salter, S., Douglas, T., \& Kember, D. (2017). Comparing face-to-face and asynchronous online communication as mechanisms for critical reflective dialogue. Educational Action Research, 25(5), 790-805.

St. Amour, M. (Sept 2020). The moment is primed for asynchronous learning. Insider Higher Ed. https://www.insidehighered.com/news/2020/09/16/dont-dismiss-asynchronous-learning-expertssay-improve-it 